\title{
IMPLEMENTASI CORPORATE SOCIAL RESPONSIBILITY (CSR) DI HOTEL DAN PENGARUHNYA TERHADAP CITRA MEREK DAN KESETIAAN PELANGGAN
}

\author{
Astrid Livia ${ }^{1}$ Gladys $^{2}$, Serli Wijaya ${ }^{3 *}$ \\ 1,2,3 Fakultas Bisnis dan Ekonomi, Universitas Kristen Petra, Surabaya \\ E-mail: ${ }^{1}$ astridlivia@gmail.com; ${ }^{2}$ frederikagladys@hotmail.com; ${ }^{3}$ serliw@petra.ac.id \\ *Penulis korespondensi
}

\begin{abstract}
Abstrak
Dalam beberapa dekade terakhir, tuntutan bahwa kehadiran entitas bisnis tidak hanya untuk mengejar keuntungan semata namun harus dapat berdampak positif bagi lingkungan dan masyarakat lokal menjadi semakin tinggi. Penelitian ini dilakukan untuk menganalisa apakah CSR yang dilakukan sebuah hotel berpengaruh terhadap citra merek dan kesetiaan pelanggannya. Penelitian ini menggunakan pendekatan kuantitatif kausal dengan melaksanakan survei lapangan berbasis kuesioner yang dibagikan kepada 200 responden yang pernah menginap di salah satu dari properti Pop! Hotels di Indonesia. Menggunakan teknik analisa statistik Partial Least Square (PLS), hasil penelitian menunjukkan bahwa CSR berpengaruh positif dan signifikan terhadap citra merek dan kesetiaan pelanggan. Selain itu, citra pelanggan terhadap merek hotel terbukti menjadi mediator bagi pengaruh tidak langsung CSR terhadap kesetiaan pelanggan
\end{abstract}

Kata kunci: Corporate social responsibility; citra merek; kesetiaan pelanggan; hotel; Surabaya.

\section{Abstract}

In the past few decades, there has been an increasing demand that every business entities should not pursue the profit alone, but it needs to pay attention on the environment and societies' welfare too. This research aimed to analyze the impact of CSR on brand image and customer loyalty. Survey was conducted to 200 respondents who have stayed at one of Pop! Hotels Indonesia properties. The result showed that CSR had a positive and significant impact on brand image and customer loyalty. Moreover, CSR also had an indirect impact on customer loyalty with brand image as the intervening variable.

Keywords: Corporate social responsibility; brand image; customer loyalty; hotel; Surabaya

\section{PENDAHULUAN}

Dalam beberapa tahun terakhir, pertumbuhan ekonomi di Surabaya mengalami peningkatan terutama di bidang perhotelan, dengan adanya peningkatan jumlah hotel sebanyak 125 hotel pada tahun 2014 menjadi 189 hotel untuk tahun 2015 mulai dari hotel non bintang sampai bintang lima (BPS, 2016). Pertumbuhan ini mendorong persaingan yang semakin ketat dalam industri perhotelan dimana setiap hotel dituntut untuk dapat mempertahankan diri dalam persaingan secara jangka panjang. Salah satu strategi yang dapat diterapkan untuk menciptakan daya saing berkelanjutan tanpa menimbulkan dampak negatif terhadap masyarakat dan lingkungan adalah dengan menerapkan Corporate Social Responsibility (CSR). Menurut Du, Bhattacharya, dan Sen (2011), CSR tidak hanya sekedar tanggung jawab etis yang harus dilakukan perusahaan, melainkan dapat menjadi salah satu cara untuk mencapai tujuan perusahaan dengan memaksimalkan dimensi ekonomi, sosial dan lingkungan untuk jangka panjang melalui praktek dan kebijakan bisnis yang diambil. Haliwela (2013) menyatakan bahwa CSR merupakan sebuah strategi dimana perusahaan tidak lagi dihadapkan pada tanggung jawab yang berpijak pada single bottom line, yaitu nilai perusahaan (corporate value) yang direfleksikan pada kinerja keuangannya (financial performance) semata, namun juga tanggung jawab perusahaan harus berpijak pada aspek sosial dan lingkungan.

Selain aktivitas CSR, hal yang tidak kalah menarik dalam persaingan untuk memenangkan konsumen saat ini adalah citra merek. Citra merek menurut Kotler (2008) merupakan seperangkat keyakinan, ide, dan kesan yang dimiliki oleh seseorang terhadap suatu merek. Merek mencerminkan segala sesuatu yang dilakukan perusahaan, dan akan dinilai oleh masyarakat (Singh, Islam, \& Ariffin, 2014). Hal inilah yang menyebabkan mengapa citra merek sangat diperlukan dan membuat banyak perusahaan berlomba untuk mendapatkan citra merek yang positif dari masyarakat dan konsumennya. Dalam kaitannya dengan citra mereka, Singh et al. (2014) menyatakan bahwa CSR merupakan salah satu strategi yang bisa membentuk citra merek perusahaan yang positif dan menguntungkan. Aghekyan-Simonian et al. (2012) berpendapat, seperti dikutip dalam Che, Min, Li, dan Kuo (2015) 
bahwa konsumen akan cenderung senang untuk membayar atau membeli produk jasa yang sudah mempunyai merek ternama. Inilah yang menjadi salah satu keuntungan yang didapat oleh perusahaan jika mampu memberikan bukti citra merek yang positif, dan justru akan membentuk suatu loyalitas dari pelanggan. Menurut Hurriyati (2008) kesetiaan pelanggan adalah komitmen pelanggan bertahan secara mendalam untuk berlangganan kembali atau melakukan pembelian ulang produk/jasa terpilih secara konsisten di masa yang akan datang.

Studi ini memilih Pop! Hotels di Indonesia sebagai objek yang diteliti. Pop! Hotels merupakan sebuah merek hotel yang tergabung dalam Tauzia Hotel Management yang didirikan pada tahun 2001. Selain Pop! Hotels, ada beberapa merek lain yang berada di bawah Tauzia Hotel Management antara lain: Préférence, Harris Vertu, Harris Hotel, Fox Harris, Yellow, Pop! dan Tauzia Estate Management. Berbagai program CSR diterapkan oleh Tauzia Hotel Management. Sebagai contoh program Equal Chance yang dilakukan oleh semua properti bawah Tauzia Hotel Management. Program ini bertujuan untuk memberikan pendidikan kepada anak-anak kurang mampu untuk mencegah anak-anak tersebut menjadi gelandangan atau menjadi buruh anak (CSR-Equal Chance, 2012). Pop! Hotel sendiri merupakan salah satu budget hotel yang dikelola oleh Tauzia Hotel Management. Dengan tagline "Feel Free" dan konsep budget hotel untuk eco-friendly traveller. Target pasar dari Pop! Hotels sendiri adalah traveller muda dan melalui aktivitas CSRnya, Pop! Hotels ingin menanamkan kesadaran eco-friendly kepada para konsumen muda yang menginap ("Pop! Hotels", 2017). Selain Equal Chance, Pop! Hotels juga melakukan CSR berupa program recycle. Program recycle yang dilakukan Pop! Hotels dapat dilihat dari beberapa hiasan yang terbuat dari barang-barang bekas seperti botol bekas, kaleng bekas, dan lain-lain.

Berdasarkan kajian literatur yang telah dilakukan oleh penulis, studi tentang CSR dan hubungannya dengan brand image maupun customer loyalty sudah banyak dilakukan di luar Indonesia (Martínez, Pérez, dan Bosque, 2013). Namun demikian, penelitian mengenai pengaruh CSR terhadap brand image dan customer loyalty pada industri perhotelan di Indonesia, terutama di Surabaya masih belum pernah dilakukan. Berpijak pada kesenjangan ini, penulis ingin mengetahui apakah CSR berpengaruh terhadap citra merek dan kesetiaan pelanggan khususnya pada Pop! Hotels di Indonesia.

\section{TINJAUAN PUSTAKA}

\section{Corporate Social Responsibility (CSR)}

Menurut Sarosa dan Amri (2008), Corporate Social Responsibility (CSR) adalah upaya yang dilakukan perusahaan untuk mencapai pembangunan yang berkelanjutan dengan adanya keseimbangan tiga pilar, yaitu ekonomi, sosial, dan lingkungan. Ketiga pilar inilah yang menjadi dasar bagi perusahaan dalam melakukan CSR. Sedangkan The World Business Council for Sustainable Development dan Hadi (2011) mendefinisikan CSR sebagai komitmen atau bentuk tindakan dari bisnis atau perusahaan untuk berperilaku etis dan berkontribusi terhadap pembangunan atau peningkatan ekonomi yang berkelanjutan, untuk meningkatkan kualitas hidup karyawan dan keluarganya, komunitas lokal dan masyarakat luas. Pengertian ini menjabarkan bahwa setiap tindakan perusahaan haruslah memiliki nilai etis yang menghargai masyarakat sekitar.

Kotler dan Lee (2005) mendefinisikan CSR sebagai komitmen perusahaan untuk meningkatkan kesejahteraan komunitas melalui praktik bisnis yang baik dan mengkontribusikan sebagian sumber daya perusahaan. Berdasarkan definisi di atas, dapat disimpulkan bahwa CSR adalah komitmen dan tindakan etis perusahaan untuk meningkatkan kesejahteraan ekonomi, kualitas hidup karyawan dan keluarganya, serta masyarakat lokal.

\section{Dimensi CSR}

Martinez, Perez, dan Bosque (2013) menjabarkan tiga dimensi CSR antara lain:

1. Dimensi ekonomi (economic dimension)

Dimensi ekonomi merupakan tanggung jawab dari bisnis hotel untuk memproduksi barang atau jasa sesuai dengan keinginan masyarakat dan bertujuan mendapatkan keuntungan jangka panjang. Dimensi ekonomi ini diukur dengan indikator sebagai berikut:

a) mendapatkan keuntungan sebesar-besarnya

b) mencoba mencapai kesuksesan jangka panjang

c) meningkatkan kinerja ekonomi perusahaan

d) memastikan dapat bertahan di pasaran jangka panjang

2. Dimensi sosial (social dimension)

Dimensi sosial merupakan kepedulian dan sikap saling menghargai terhadap orang lain maupun sesama yang dikembangkan oleh hotel dalam kegiatan operasional bisnisnya dimana hotel tersebut berada. Dimensi ini bisa ditunjukkan dengan indikator sebagai berikut: 
a) komitmen untuk meningkatkan kesejahteraan komunitas atau masyarakat sekitar

b) aktif berpartisipasi dalam kegiatan sosial dan budaya sekitar

c) memberikan perlakuan yang adil antar karyawan

d) memberikan dan menyediakan pelatihan atau kesempatan promosi untuk karyawan (pemberdayaan karyawan)

e) membantu memecahkan masalah sosial

3. Dimensi lingkungan (environmental dimension)

Dimensi lingkungan mencerminkan usaha bisnis hotel yang membantu dan meminimaliskan dampak negatif yang timbul ke lingkungan sekitar. Indikator untuk mengukur dimensi lingkungan adalah:

a) menjaga kelestarian lingkungan

b) meminimalisir penggunaan sumber daya alam

c) pemberlakuan recycle

d) adanya pemberitahuan akan adanya program pemberdayaan lingkungan partisipasi dalam sertifikasi lingkungan

\section{Citra Merek}

Branding bukanlah sebagai strategi pemasaran dari perusahaan yang hanya sekedar memberi nama, melainkan juga sebagai pencitraan dari tindakan apa saja yang dilakukan oleh perusahaan dan nantinya akan membantu konsumen atau pihak lain dalam menilai reputasi atau citra perusahaan tersebut baik atau buruk (Singh et al., 2014). Sedangkan citra merek adalah pengembangan pikiran dari pelanggan yang diakibatkan adanya promosi, word of mouth, iklan terhadap barang atau jasa (Kandampully \& Dwi, 2003).

Citra merek didefinisikan oleh Kotler (2008) sebagai seperangkat keyakinan, ide, dan kesan yang dimiliki oleh seseorang terhadap suatu merek, karena itu sikap dan tindakan konsumen terhadap suatu merek sangat ditentukan oleh citra merek tersebut. Dari penjelasan di atas maka dapat disimpulkan bahwa citra merek merupakan kumpulan kesan atau ide tertentu yang bermakna bagi pelanggan dan mampu menentukan sikap serta tindakan selanjutnya dari pelanggan terhadap suatu merek.

\section{Dimensi Citra Merek}

Martinez et al., (2013) menyatakan bahwa citra merek memiliki dua dimensi yaitu fungsional (functional) dan afektif (affective). Pertama, dimensi fungsional menggambarkan sesuatu yang nyata seperti barang atau jasa untuk memenuhi kebutuhan tamu dalam mendapatkan kepuasan melalui lingkungan fisik. Indikator dari dimensi ini adalah: a) jasa yang ditawarkan berkualitas tinggi; b) jasa yang ditawarkan memiliki fitur yang lebih baik dibandingkan pesaingnya; dan c) jasa yang ditawarkan biasanya lebih mahal dibandingkan pesaing. Dimensi yang kedua adalah afektif, yang berkaitan dengan psikologi dan emosi konsumen seperti kebanggaan, rasa kepercayaan terhadap suatu merek. Terdapat empat indikator dari dimensi ini antara lain: a) merek ini membangkitkan simpati; b) merek menunjukkan kepribadian yang berbeda dari pesaingnya; c) merek menggunakan merek ini akan menunjukkan identitas pemakainya; dan d) merek memiliki gambaran mengenai identitas pemakainya.

\section{Kesetiaan pelanggan}

Loyalitas adalah komitmen pelanggan untuk bertahan dan berlangganan kembali atau melakukan pembelian ulang barang atau jasa terpilih secara konsisten di masa yang akan datang dan menyebabkan pembelian merek yang sama secara berulang terlepas dari pengaruh keadaan dan upaya pemasaran yang bisa menyebabkan switching behavior (Hurriyati, 2008). Sementara menurut Yi dan La (2004), kesetiaan pelanggan berarti pelanggan tidak hanya mempunyai komitmen seperti yang diutarakan Hurriyati (2008), namun juga cenderung melakukan word-of-mouth, tidak mudah untuk beralih pada merek pesaing, dan berani untuk membayar harga premium demi kesetiaannya pada sebuah merek.

Mark, Grahamme, dan Hammond (2003) menyatakan bahwa loyalitas pelanggan berarti pelanggan mempunyai motivasi dan komitmen untuk mempunyai hubungan dengan suatu merek. Dengan demikian, dapat disimpulkan bahwa kesetiaan pelanggan dapat dilihat dari pelanggan yang mempunyai komitmen untuk selalu berhubungan dengan suatu merek yang sama, melalui pembelian secara berulang-ulang dimasa datang dan tidak segan membayar dengan harga berapapun untuk mendapatkannya.

\section{Dimensi Kesetiaan Pelanggan}

Kandampully dan Suhartanto (2003) menjelaskan bahwa terdapat lima indikator untuk mengukur kesetiaan pelanggan yaitu:

1. Mengatakan hal positif mengenai perusahaan

2. Merekomendasikan perusahaan kepada orang lain

3. Meyakinkan orang lain untuk bekerja sama dengan perusahaan tersebut

4. Mempertimbangkan perusahaan tersebut sebagai pilihan pertama

5. Memilih untuk melakukan kerja sama lebih dengan perusahaan 


\section{Hubungan Antar Konsep}

\section{Hubungan CSR dengan Citra Merek}

Menurut Chan (2011) dalam Martinez et al. (2013), CSR merupakan strategi perusahaan dalam sektor hospitality yang berfungsi mengurangi dampak negatif kegiatan perusahaan pada lingkungan alam, budaya dan sosial. Dalam hal ini CSR mampu membantu perusahaan untuk mendapatkan predikat citra merek yang positif, dimana dampak negatif perusahaan dapat dikurangi. Terkait dengan citra merek, dalam membangun merek yang kuat, suatu perusahaan khususnya hotel harus mengembangkan cara untuk membedakan antara citra hotel dengan para kompetitornya (Che et al. 2015). Dalam hal ini CSR dapat memberikan dorongan untuk mendapatkan predikat tersebut, dikarenakan konsumen tidak hanya melihat kualitas produk jasa yang dihasilkan oleh perusahaan, melainkan secara tidak langsung juga melihat dari sisi etika berbisnisnya. Menurut Singh et al. (2014) CSR merupakan salah satu cara positif yang bisa membentuk citra merek dan menguntungkan perusahaan serta mampu mengurangi dampak negatif dari perusahaan tersebut.

Berdasarkan penelitian sebelumnya yang dilakukan oleh Martinez et al. (2013), CSR memiliki pengaruh yang signifikan terhadap citra merek, terutama pada dimensi afektif. Selain itu, pada penelitian yang dilakukan oleh Stephanie dan Chandra (2012), menunjukan hasil yang sama, yaitu CSR memiliki pengaruh yang signifikan terhadap citra merek. Dari hasil penelitian tersebut maka dapat ditarik hipotesis bahwa seluruh dimensi CSR memiliki pengaruh terhadap dimensi citra merek. Dalam penelitian ini dimensi CSR yang digunakan hanya sosial dan lingkungan, sedangkan dimensi ekonomi tidak digunakan dengan alasan dimensi tersebut kurang terlihat oleh konsumen secara langsung maupun tidak langsung sehingga tidak bisa menyampaikan persepsi konsumen mengenai CSR. Dan juga dimensi ekonomi bertujuan untuk mendapatkan keuntungan jangka panjang perusahaan dan hanya menjadi data internal perusahan itu sendiri. Pada penelitian milik Martinez et al. (2013) dimensi ekonomi juga berkorelasi negatif dengan kedua dimensi lainnya. Maka dari itu, penulis memutuskan untuk tidak menggunakan dimensi ekonomi dalam penelitian ini. Berdasarkan kajian literatur di atas, maka hipotesis pertama dirumuskan sebagai berikut:

$\mathrm{H}_{1}$ : CSR yang dilakukan hotel berpengaruh positif dan signifikan terhadap citra merek.

\section{Hubungan Citra Merek dengan Kesetiaan Pelanggan}

Aghekyan-Simonian et al. (2012) berpendapat, seperti dikutip dalam Che et al. (2015) bahwa konsumen akan cenderung senang untuk membayar atau membeli produk jasa yang sudah mempunyai merek ternama. Inilah yang menjadi salah satu keuntungan yang didapat oleh perusahaan jika mampu memberikan bukti citra merek yang positif, dan justru akan membentuk suatu loyalitas dari pelanggan. Hal ini membuktikan bahwa semakin baik citra merek di mata konsumen, akan semakin meningkatkan kesetiaan pelanggan.

Penelitian sebelumnya mengenai citra merek dan kesetiaan pelanggan sudah pernah dilakukan oleh Kandampully dan Suhartanto (2003), serta Ogba dan Tan (2009). Pada penelitian yang dilakukan oleh Kandampully dan Suhartanto (2003), beliau menganalisa faktor-faktor pada citra hotel dan kepuasan yang membuat pelanggan di jaringan hotel di Christchurch, New Zealand menjadi loyal. Hasil dari penelitian tersebut sama dengan penelitian yang dilakukan Ogba dan Tan (2009), meskipun konteks penelitiannya dilakukan terhadap pasar mobile phone di Cina, namun hasilnya mengungkap bahwa citra merek mampu mempengaruhi kesetiaan pelanggan sekaligus mampu meningkatkan komitmen pelanggan. Berdasarkan hasil kajian literatur ini maka dapat disimpulkan bahwa citra merek memiliki pengaruh terhadap kesetiaan pelanggan. Berdasarkan kajian literatur di atas, maka hipotesis kedua dirumuskan sebagai berikut:

$\mathrm{H}_{2}$ : Citra merek hotel berpengaruh positif dan signifikan terhadap kesetiaan pelanggan

\section{Hubungan CSR dengan Kesetiaan Pelanggan}

Dalam hubungan antara CSR dan kesetiaan pelanggan, Martinez et al. (2013) menyatakan bahwa ada pengaruh langsung dan tidak langsung dari CSR ke kesetiaan pelanggan. Hasil penelitian Martinez et al. (2013) menunjukkan bahwa CSR berpengaruh terhadap citra merek dan citra merek berpengaruh terhadap kesetiaan pelanggan, namun CSR juga bisa berpengaruh secara langsung terhadap kesetiaan pelanggan. Sementara itu dari penelitian Stephanie dan Chandra (2012) menunjukkan bahwa CSR berpengaruh secara tidak langsung terhadap kesetiaan pelanggan dengan citra merek sebagai variabel intervening. Terlepas dari adanya pengaruh secara langsung maupun tidak langsung, penulis menyimpulkan bahwa 
dari hasil penelitian sebelumnya dapat ditarik hipotesis, CSR berpengaruh terhadap kesetiaan pelanggan. Berdasarkan kajian literatur di atas, maka hipotesis ketiga dirumuskan sebagai berikut:

$\mathrm{H}_{3}$ : CSR berpengaruh secara langsung, positif, dan signifikan terhadap kesetiaan pelanggan.

$\mathrm{H}_{4}$ : CSR berpengaruh secara positif dan signifikan terhadap kesetiaan pelanggan dengan citra merek sebagai variabel intervening.

\section{METODE PENELITIAN}

\section{Jenis Penelitian}

Penelitian ini menggunakan metode kuantitatif yang menggunakan rumusan masalah asosiatif dengan pola hubungan kausal. Menurut Kuncoro (2007) metode kuantitatif adalah pendekatan ilmiah yang berdasarkan pada data dan digunakan untuk pengambilan keputusan manajerial dan ekonomi. Dalam penelitian ini terdapat 3 variabel yang diuji dan dianalisa. Pertama, variabel independen dari penelitian ini adalah Corporate Social Responsibility (CSR) karena tidak dipengaruhi oleh variabel manapun. Kedua adalah variabel citra merek yang mau dibuktikan sebagai variabel intervening karena berada di antara variabel independen dan dependen. Sedangkan yang terakhir yaitu variabel kesetiaan pelanggan sebagai variabel dependen karena dipengaruhi oleh variabel-variabel sebelumnya.

\section{Populasi dan Sampel}

Populasi penelitian ini adalah konsumen yang pernah menginap di Pop! Hotels Indonesia, dimana Pop! Hotels merupakan salah satu hotel dibawah naungan Tauzia Hotel Management. Namun, untuk mempermudah peneliti menggunakan teknik sampling non-probability sampling yaitu purposive sampling dengan pertimbangan kriteria sampel sebagai berikut:

1. Responden merupakan konsumen yang sudah pernah menginap di Pop! Hotels di Indonesia.

\section{Berusia minimal 17 tahun}

Menurut Roscoe (1992) dalam Sugiyono (2013), ukuran sampel yang layak digunakan dalam penelitian adalah antara 30 sampai dengan 500 .

Namun jika penelitian menggunakan analisa multivariat (korelasi atau regresi ganda) maka jumlah anggota sampel minimal 10 kali dari jumlah variabel yang diteliti.
Dalam hal ini penulis mempunyai 18 variabel yang terdapat pada lembar kuesioner. Sehinga jumlah minimum sampel adalah $10 \times 18=180$, dan untuk mengantisipasi kesalahan pengambilan sampel saat pengumpulan data maka penulis menentukan jumlah sampel yang diambil sebanyak 200 orang.

Peneliti melakukan observasi mengenai kegiatan CSR hotel melalui media sosial instagram Pop! Hotels yang dilanjutkan dengan melakukan survei dengan kuesioner sebagai instrumen penelitiannya. Kuesioner yang dibagikan bersifat tertutup dan terdiri dari dua bagian. Bagian pertama adalah profil responden, meliputi poin pertanyaan mengenai profil demografis responden. Bagian kedua berisi 18 poin pernyataan terkait persepsi konsumen terhadap CSR, citra merek, dan kesetiaan pelanggan. Kuesioner yang disebarkan berjumlah 200 buah dan disebarkan secara offline dan online masing-masing 100 buah. Skala pengukuran dalam kuisioner menggunakan 7 poin Likert scale dengan skor 1 (amat sangat tidak setuju) sampai 7 (amat sangat setuju).

Sebelum melakukan survei, peneliti melakukan uji validitas dan reliabilitas dengan bantuan pre-test yang disebarkan pada 30 responden sesuai dengan ketentuan kriteria penulis. Jenis uji validitas yang digunakan adalah korelasi pearson product moment yang menyatakan bahwa jika nilai signifikansi lebih kecil dari tingkat kesalahan yang ditoleransi (yaitu $\alpha=$ $0,05)$ maka dapat disebut valid. Sedangkan jenis uji reliabilitas menggunakan cronbach's alpha. Disebut reliabel apabila nilai cronbach's alpha $>0.6$. Dapat disimpulkan bahwa, seluruh poin pernyataan kuesioner yang digunakan untuk mengukur setiap variabel dalam penelitian ini valid dan reliabel. Oleh karena itu, penulis dapat melanjutkan penelitian ke tahap selanjutnya yaitu menyebarkan kuisioner ke 200 responden.

\section{Teknik Analisa Data}

Untuk menunjang perhitungan analisis data, penulis menggunakan program Structural Equation Modeling (SEM). Menurut Jogiyanto (2011) SEM merupakan suatu teknik statistika yang digunakan untuk menguji dan mengestimasi hubungan kausal dengan mengintegrasikan analisis faktor dan analisis jalur serta regresi berganda yang menjadi bagian utamanya. Penelitian ini menggunakan analisa SEM dengan menggunakan Partial Least Square (PLS). 


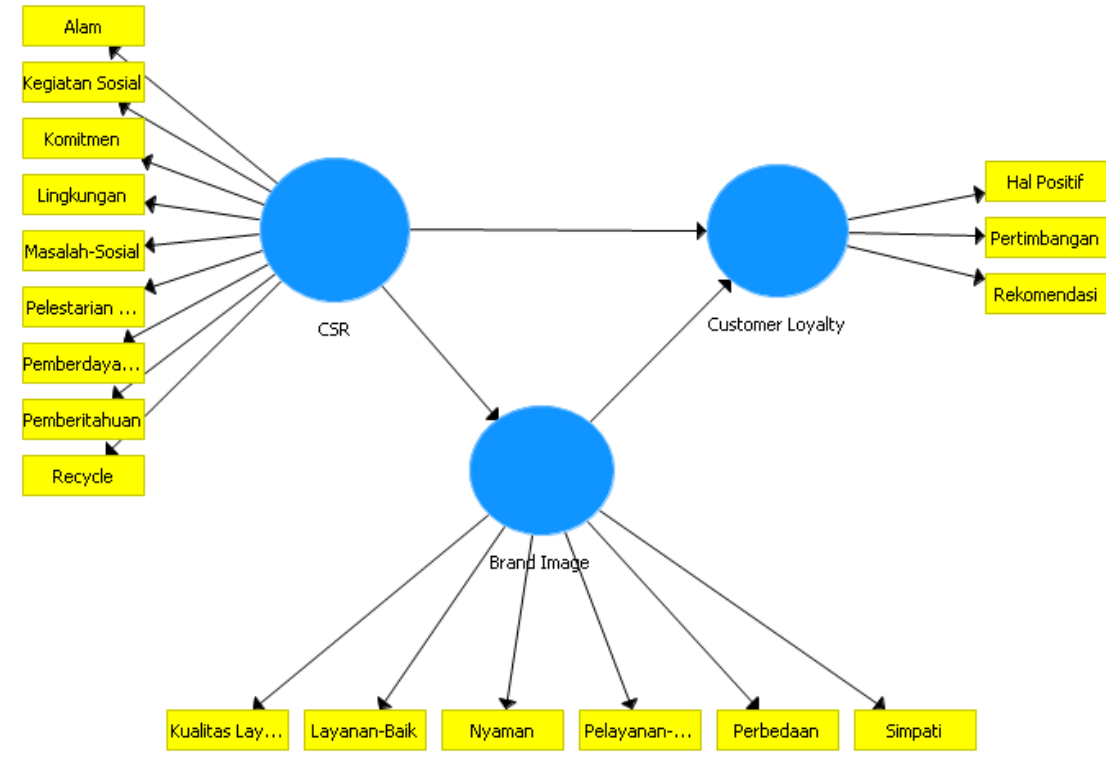

Gambar 1. Model Partial Least Square

\section{HASIL DAN PEMBAHASAN}

\section{Profil Responden}

Dari 202 kuesioner yang disebar, hanya 182 kuesioner yang dapat diolah lebih lanjut. Sehingga response rate responden sebesar $90,10 \%$. Pada Tabel 1 terlihat bahwa dari 182 responden yang pernah menginap di Pop! Hotels di Indonesia, didominasi oleh wanita sebanyak 103 orang $(56,6 \%)$, berusia $17-22$ tahun yaitu sebanyak 98 orang $(53,8 \%)$. Hasil tersebut menunjukkan bahwa responden terkumpul yang pernah menginap di Pop! Hotels didominasi pada kaum muda dimana hal ini sesuai dengan pasar sasaran dari Pop! Hotels sendiri yang adalah smart young traveller yang didominasi oleh anak-anak muda.

Tabel 1. Profil Responden

\begin{tabular}{llll}
\hline No & Atribut Demografis & $\mathrm{n}$ & $\%$ \\
\hline 1. & Jenis kelamin: & & \\
& Pria & 79 & $45,1 \%$ \\
& Wanita & 103 & $56,6 \%$ \\
2. & Usia: & & \\
& 17-22 tahun & 98 & $53,8 \%$ \\
& 23-56 tahun & 78 & $42,9 \%$ \\
& 57-65 tahun & 6 & $3,3 \%$ \\
& >65 tahun & - & - \\
3. Jenis pekerjaan: & & \\
& Pelajar/mahasiswa & 82 & $45,1 \%$ \\
& Ibu rumah tangga & 6 & $3,3 \%$ \\
& Profesional & 10 & $5,5 \%$ \\
& Wiraswasta & 29 & $15,9 \%$ \\
& Karyawan & 53 & $29,2 \%$ \\
& Tidak bekerja & 1 & $0,5 \%$ \\
& Lainnya & 1 & $0,5 \%$ \\
\hline
\end{tabular}

\section{Hasil Pengujian Outer Model}

a. Validitas Konvergen

Berdasarkan hasil validitas konvergen, seluruh poin indikator dinyatakan valid karena nilai outer loading yang diperoleh melebihi 0,7. Tetapi untuk poin indikator pertama dan kedua belas memiliki nilai outer loading di bawah 0,7 , Sehingga penulis memutuskan untuk melihat berdasarkan nilai AVE. menurut Jogiyanto (2011) jika dalam penelitian terdapat nilai outer loading antara 0,50,7 dan skor AVE serta communality indicator > 0,5 sebaiknya penulis tidak menghapus indikator tersebut. Indikator pertama terletak pada CSR dengan nilai AVE 0,617 dan indikator ke-12 terletak pada citra merek yang nilai AVE nya 0,664 sehingga dengan demikian penulis memutuskan tidak menghapus kedua indikator tersebut dikarenakan nilai AVE yang lebih dari 0,5.

\section{b. Validitas Diskriminan}

Berikutnya adalah validitas diskriminan. Suatu indikator dikatakan memenuhi validitas diskriminan jika nilai cross loading indikator terhadap variabelnya adalah yang terbesar dibandingkan variabel lainnya (Jogiyanto, 2011). Berdasarkan hasil validitas diskriminan, seeluruh nilai cross loading poin indikator mendukung masing-masing variabel.

c. Cronbach Alpha

Cronbach's alpha digunakan untuk mengukur batas bawah nilai reliabilitas suatu konstruk. Nilai cronbach's alpha $>0.6$ dapat dikatakan reliabel (Jogiyanto, 2011). Berdasarkan nilai cronbach's 
alpha, indikator masing-masing variabel pada penelitian ini semua memiliki nilai yang lebih dari 0,6 maka dari itu indikator masing pada variabelvariabel penulis sudah memenuhi syarat cronbach's alpha dan dikatakan reliabel.

d. Composite Reliability

Dikatakan memenuhi composite reliability apabila nilainya lebih besar dari 0,7 (Jogiyanto, 2011). Berdasarkan composite reliability, masing-masing variabel atau konstruk semuanya memenuhi syarat composite reliability yang melebihi 0,7 .

e. $R^{2}$ dan Goodness of Fitness $\left(Q^{2}\right)$

Hal yang pertama dilakukan saat melihat nilai Rsquare $\left(\mathrm{R}^{2}\right)$ adalah emakin tinggi nilai $\mathrm{R}^{2}$ berarti semakin baik model penelitian dalam memprediksi hubungan antar variabel laten yang diteliti. Untuk nilai $R^{2}$ variabel citra merek, sebesar 0,670 yang berarti citra merek dapat dijelaskan oleh variabel CSR sebesar 67\%. Sedangkan sisanya sebesar 33\% dijelaskan oleh faktor lain diluar konteks penulis. Sedangkan untuk kesetiaan pelanggan mempunyai nilai $\mathrm{R}^{2}$ sebesar $67,4 \%$ yang berarti bahwa kesetiaan pelanggan dapat dijelaskan sebesar $67,4 \%$ oleh variabel CSR. Dan 32,6\% sisanya dijelaskan oleh faktor lain diluar konteks penulis. Nilai $\mathrm{Q}^{2}$ memiliki arti yang sama dengan $\mathrm{R}^{2}$, dimana semakin tinggi $\mathrm{R}^{2}$ maka model dikatakan semakin fit dengan data. Dengan hasil $\mathrm{Q}^{2}$ yang lebih besar dari 0 yaitu 0,884 maka model penelitian memiliki predictive relevance atau dengan kata lain model penelitian ini layak untuk digunakan. Yang berarti keseluruhan model yang dihitung mulai $\mathrm{R}^{2}$ hingga model yang diprediksi dibandingkan dengan data sebenarnya memiliki tingkat kesesuaian sebesar $88,4 \%$.

\section{Pengujian Hipotesis}

Hipotesis penelitian dapat diterima jika nilai thitung (t-statistic) lebih tinggi dibandingkan nilai ttable pada tingkat kesalahan $\alpha=5 \%(1,96)$.

Tabel 2. Hasil Nilai Original Sample dan T-Statistic

\begin{tabular}{|c|c|c|c|}
\hline & $\begin{array}{l}\text { Original } \\
\text { Sample }\end{array}$ & T-statistic & Kesimpulan \\
\hline CSR- > Citra merek & 0,819 & 29,956 & (+) signifikan \\
\hline $\begin{array}{l}\text { Citra merek -> } \\
\text { Kesetiaan pelanggan }\end{array}$ & 0,566 & 6,886 & (+) signifikan \\
\hline $\begin{array}{l}\text { CSR -> Kesetiaan } \\
\text { pelanggan }\end{array}$ & 0,273 & 3,382 & (+) signifikan \\
\hline
\end{tabular}

Berdasarkan Tabel 2, nilai original sample CSR terhadap citra merek adalah 0,819 dengan t-statistic 29,956 lebih besar dari t-table yang artinya terdapat pengaruh positf dan signifikan antara CSR dan citra merek. Hal ini berarti bahwa semakin positif persepsi responden terhadap aktivitas CSR yang dilakukan sebuah hotel maka hal ini berpengaruh terhadap citra merek yang semakin positif juga dari hotel tersebut. Dengan demikian hipotesis pertama bahwa CSR berpengaruh positif dan signifikan terhadap citra merek dapat diterima.

Nilai original sample dari citra merek terhadap kesetiaan pelanggan adalah 0,566 dengan t-statistic 6,886 yang lebih besar pula dari t-table dengan arti terdapat pengaruh yang positif dan signifikan antara citra merek dan kesetiaan pelanggan. Hal ini berarti semakin baik citra merek suatu hotel dimata konsumen maka kesetiaan pelanggan semakin tinggi. Dengan demikian hipotesis kedua bahwa citra merek berpengaruh positif dan signifikan terhadap kesetiaan pelanggan dapat diterima.

Nilai original sample terakhir adalah CSR terhadap kesetiaan pelanggan sebesar 0,273 dengan tstatistic 3,382 yang juga lebih besar dari t-table yang artinya terdapat pengaruh positif dan signifikan antara CSR dan kesetiaan pelanggan. Semakin baik persepi konsumen mengenai CSR suatu hotel maka semakin tinggi kesetiaan pelanggan. Dengan demikian hipotesis ketiga yang menyatakan bahwa CSR berpengaruh positif dan signifikan terhadap kesetiaan pelanggan secara langsung dapat diterima.

Tabel 3. Hasil Direct dan Indirect Effect

\begin{tabular}{lcc}
\hline & $\begin{array}{c}\text { Direct } \\
\text { Effect }\end{array}$ & Indirect Effect \\
\hline CSR-> Citra merek & 0,819 & \\
Citra merek -> Kesetiaan pelanggan & 0,566 & \\
$\begin{array}{l}\text { CSR -> Kesetiaan pelanggan } \\
\text { CSR terhadap Kesetiaan pelanggan }\end{array}$ & 0,273 & \\
melalui Citra merek & & $\begin{array}{c}0,819 * 0,566 \\
=0,464\end{array}$ \\
\hline
\end{tabular}

Tabel 3 menunjukkan nilai direct effect CSR terhadap kesetiaan pelanggan sebesar 0,273 dimana hal ini berarti terdapat pengaruh secara langsung antara CSR dan kesetiaan pelanggan. Sedangkan untuk indirect effect CSR terhadap kesetiaan pelanggan sebesar 0,464. Dari hasil indirect effect maka dapat disimpulkan CSR mempengaruhi kesetiaan pelanggan dengan bantuan citra merek sebagai variabel intervening-nya secara positif dan signifikan, sehingga hal ini menunjukkan adanya pengaruh yang tidak langsung. Hipotesis keempat, penulis menduga adanya pengaruh positif dan signifikan antara CSR terhadap kesetiaan pelanggan dengan citra merek sebagai variabel intervening.

Penelitian ini bertujuan untuk mengetahui pengaruh persepsi CSR terhadap citra merek dan pengaruh citra merek terhadap kesetiaan pelanggan pada Pop! 
Hotel. Penelitian ini juga ingin mengetahui mengenai pengaruh persepsi CSR terhadap kesetiaan pelanggan dengan citra merek sebagai variabel intervening. Selain pengaruh tidak langsung, penulis juga ingin meneliti pengaruh langsung persepsi CSR terhadap kesetiaan pelanggan di Pop! Hotel. Tabel 4 menunjukkan hasil pengujian hipotesis sebagai berikut:

Tabel 4. Kesimpulan Hipotesis

\begin{tabular}{clcc}
\hline $\begin{array}{c}\text { Hipo- } \\
\text { tesis }\end{array}$ & Hipotesis Penulis & Hasil Uji & Kesimpulan \\
\hline 1 & CSR-> Citra merek & $\begin{array}{l}\text { (+) Signifikan } \\
2\end{array}$ & Terbukti \\
& $\begin{array}{l}\text { Citra merek-> } \\
\text { Kesetiaan pelanggan }\end{array}$ & (+) Signifikan & Terbukti \\
3 & $\begin{array}{l}\text { CSR }->\text { Kesetiaan } \\
\text { pelanggan }\end{array}$ & (+) Signifikan & Terbukti \\
4 & $\begin{array}{l}\text { CSR terhadap } \\
\text { Kesetiaan pelanggan } \\
\text { melalui Citra merek }\end{array}$ & (+) Signifikan & Terbukti \\
\hline
\end{tabular}

\section{Pengaruh CSR terhadap citra merek}

CSR dapat diukur dengan dua dimensi yaitu, sosial dan lingkungan. Total indikator yang merefleksikan kedua dimensi tersebut berjumlah sembilan. Secara keseluruhan responden menyatakan setuju. Hal ini terlihat dari nilai mean sebesar 5,15. Sementara pada Tabel 2 yang menunjukan tanggapan responden mengenai pengaruh CSR terhadap citra merek didapatkan nilai $t$-statistics sebesar 29,956. Nilai ini menunjukkan bahwa terdapat pengaruh positif dan signifikan antara CSR dan citra merek. Sehingga semakin baik persepsi konsumen terhadap CSR suatu hotel maka semakin baik pula citra merek hotel dimata konsumen. Berdasarkan hal ini, hipotesis pertama yaitu penulis menduga CSR berpengaruh positif dan signifikan terhadap citra merek dapat diterima, dengan maksud persepsi dari konsumen terhadap CSR mempengaruhi citra merek suatu hotel. Hasil ini mendukung penelitian yang sebelumnya dilakukan Martinez et al. (2013) yang mengukur pengaruh CSR terhadap citra merek dan loyalty pada chain hotel Spanyol di Amerika Latin. Selain itu hasil ini juga mendukung penelitan dari Stephanie dan Chandra (2012) mengenai pengaruh CSR terhadap kesetiaan pelanggan dengan citra merek sebagai varibel intervening di perusahaan asuransi Allianz. Sehingga pengaruh CSR terhadap citra merek tidak hanya berlaku pada industri perhotelan di luar negeri atau di bidang asuransi saja, melainkan dapat diterapkan di industri perhotelan di Indonesia. Hal ini juga selaras dengan apa yang tertulis pada latar belakang, dimana CSR memiliki peran dalam menciptakan citra merek yang baik di mata konsumen.
Poin pernyataan yang memiliki pengaruh paling besar dari citra merek adalah mengenai kualitas layanan yang tinggi dengan nilai mean 5,17. Poin pernyataan ini sendiri termasuk dalam functional dimension dari citra merek. Hasil ini bertolak belakang dengan penelitian yang dilakukan Martinez et al. (2013) dimana dimensi yang paling berhubungan dengan CSR adalah affective dimension. Hal ini kemungkinan disebabkan bahwa konsumen di Indonesia cenderung berfokus pada layanan atau fasilitas yang disediakan oleh hotel. Dimensi fungsional adalah dimensi yang berhubungan dengan lingkungan fisik yang nyata seperti barang atau jasa yang diberikan (Martinez et al., 2013). Hal ini mungkin berbeda dengan konsumen di Amerika Latin yang cenderung melihat rasa nyaman dan bangga jika menginap di suatu hotel.

Berkaitan dengan kebijakan CSR pada Pop! Hotel, dapat dilihat bahwa program CSR yang dilakukan oleh Pop! Hotel semakin meningkatkan kualitas layanan hotel. Dengan konsep cost-concious, smart, and eco-friendly, Pop! Hotel memiliki target pasar smart traveller yang cenderung masih berusia muda. Hal ini terlihat dari mayoritas responden yang berusia 17-22 tahun. Kualitas layanan yang tinggi dibuktikan dengan fasilitas yang mendukung salah satunya adalah koneksi internet yang cepat.

\section{Pengaruh citra merek terhadap kesetiaan} pelanggan

Selanjutnya variabel citra merek untuk penelitian ini menggunakan dua dimensi yaitu functional dan affective yang masing-masing diukur dengan 3 indikator. Secara keseluruhan, responden menyatakan setuju atas pernyataan-pernyataan mengenai indikator citra merek dengan hasil nilai mean 5,00. Menurut Kotler (2008), citra merek mampu menentukan tindakan lanjutan dari konsumen terhadap suatu brand. Mark, Grahamme, dan Hammond (2003) juga menyatakan bahwa konsumen yang bertindak untuk selalu berhubungan dengan suatu brand yang sama dikatakan sebagai kesetiaan pelanggan. Pernyataan tersebut juga didukung dengan adannya penelitian milik Kandampully dan Suhartanto (2003) mengenai faktor-faktor hotel image dan customer satisfaction yang membuat pelanggan di hotel berjaringan di Christchurch New Zealand menjadi loyal. Serta penelitian Ogba dan Tan (2009) yang melakukan penelitian di industri telepon seluler di Cina mengenai citra merek yang berpengaruh terhadap kesetiaan pelanggan dan customer commitment. Semua pernyataan dan hasil penelitian diatas ternyata 
konsisten atau sesuai dan mendukung hipotesis kedua ini, seperti hasil Tabel 2. yang menunjukan nilai $t$-statistic sebesar 6,886 dengan arti citra merek mampu mempengaruhi kesetiaan pelanggan secara positif dan signifikan. Sehingga hipotesis kedua diterima, yaitu citra merek berpengaruh secara positif dan signifikan terhadap kesetiaan pelanggan. Semakin konsumen mempunyai image yang bagus terhadap suatu brand, maka konsumen akan bertindak menjadi kesetiaan pelanggan. Hasil penelitian ini menunjukkan bahwa pengaruh citra merek terhadap kesetiaan pelanggan tidak hanya berlaku di industri mobile phone ataupun perhotelan di luar negeri, tetapi dapat berlaku di industri perhotelan di Indonesia.

\section{Pengaruh CSR terhadap kesetiaan pelanggan secara langsung}

Yang ketiga adalah mengukur pengaruh CSR terhadap kesetiaan pelanggan. Pada poin pertama sudah dijelaskan bahwa variabel CSR dalam penelitian ini menggunakan dua dimensi dengan total sembilan indikator yang diukur. Sedangkan untuk kesetiaan pelanggan langsung diukur dengan tiga indikator sesuai milik Kandampully dan Suhartanto (2003), yaitu konsumen yang mengatakan hal positif tentang hotel, rekomendasi hotel terhadap orang lain, dan menjadikan hotel menjadi pilihan pertama. Kesetiaan pelanggan menurut Yin dan La (2009) serta Mark et al. (2003) merupakan hubungan yang selalu dilakukan konsumen terhadap suatu brand yang sama melalui pembelian berulang dimasa akan datang dan tidak akan segan untuk membayar harga berapapun. Untuk penelitian ini rata-rata penilaian responden untuk pernyataan kesetiaan pelanggan sendiri mencapai 4,99 atau dikatakan responden secara keseluruhan setuju dengan poin pernyataan kesetiaan pelanggan. Sedangkan berdasarkan Tabel 2, CSR dikatakan mempengaruhi kesetiaan pelanggan ( $t$ statistic $=3,382$ ) secara positif dan signifikan, namun hasil t-statistic ini merupakan hasil dengan nilai paling rendah. Hal ini disebabkan oleh kemungkinan adanya faktor-faktor lain yang menjadi perantara antara CSR dan kesetiaan pelanggan. Hasil ini mendukung penelitian sebelumnya yang membahas hubungan kedua variabel ini dan dilakukan terhadap industri perhotelan di Amerika Latin oleh Martinez et.al (2013). Penelitian Martinez et al. (2013) menunjukkan hasil bahwa CSR berpengaruh terhadap kesetiaan pelanggan secara langsung tanpa harus melewati citra merek meskipun prosentase hasil direct dan indirect effect $\mathrm{CSR}$ berpengaruh terhadap kesetiaan pelanggan secara langsung (0.273) lebih kecil daripada yang harus menggunakan citra merek sebagai variabel intervening (0.464). Berdasarkan penelitian dan hasil analisa maka hipotesis ketiga dapat diterima, yaitu CSR berpengaruh positif dan signifikan terhadap kesetiaan pelanggan secara langsung.

4. Citra merek merupakan variabel intervening yang signifikan bagi CSR dalam mempengaruhi kesetiaan pelanggan

Variabel intervening dalam penelitian ini adalah variabel citra merek. Hipotesis yang keempat ini digunakan untuk mengukur pengaruh CSR terhadap kesetiaan pelanggan dengan citra merek sebagai variabel intervening. Seperti telah dijelaskan pada poin sebelumnya bahwa pengaruh CSR terhadap kesetiaan pelanggan secara langsung pada tabel $t$-statistic (Tabel 2) menunjukkan nilai sebesar 3.382. Nilai ini merupakan nilai yang terendah. Hal ini disebabkan adanya faktor lain yang menjadi perantara (intervening) dalam konteks penelitian ini adalah citra merek. Berdasarkan Tabel 3, indirect effect CSR terhadap kesetiaan pelanggan bernilai 0,464 . Nilai ini lebih tinggi dibandingkan direct effect yang hanya 0,273 . Hasil ini menunjukkan bahwa citra merek merupakan variabel intervening yang signifikan bagi CSR dalam mempengaruhi kesetiaan pelanggan. Sehingga dapat disimpulkan bahwa hipotesis keempat dapat diterima, yaitu terdapat pengaruh positif dan signifikan antara CSR terhadap kesetiaan pelanggan dengan citra merek sebagai variabel intervening. Hal ini memperkuat penelitian sebelumnya yang dilakukan oleh Martinez et al. (2013), dengan hasil yang sama, yaitu citra merek merupakan variabel intervening yang baik bagi CSR dalam mempengaruhi kesetiaan pelanggan. Hasil penelitian tersebut juga menunjukkan nilai indirect effect yang lebih besar daripada direct effect.

Secara keseluruhan, hasil pembahasan di atas menyatakan bahwa, persepsi konsumen mengenai CSR memiliki pengaruh langsung terhadap kesetiaan pelanggan. Tetapi pengaruh tersebut akan menjadi lebih besar jika terdapat citra merek yang menjadi perantara antara CSR dan kesetiaan pelanggan. Seperti yang sudah dibahas, CSR mampu membantu hotel mendapatkan citra merek yang positif di mata konsumen. Jika responden memberikan tanggapan yang positif atau setuju dengan poin pernyataan mengenai CSR, maka citra merek suatu hotel akan semakin baik dan mempengaruhi besarnya kesetiaan pelanggan. 
Terkait dengan Pop! Hotel, CSR yang telah dijalankan terbukti memiliki pengaruh yang positif terhadap citra merek, sehingga image Pop! Hotel di mata konsumen menjadi lebih baik. Hal ini juga berpengaruh ke kesetiaan pelanggan, dimana semakin baik citra sebuah hotel di mata konsumen, maka akan membuat konsumen semakin loyal. Bentuk CSR yang paling tampak dari Pop! Hotel adalah adanya program recycle. Hal ini terbukti dengan adanya barang-barang bekas seperti botol, ban, dan kaleng yang digunakan sebagai hiasan pada hotel. Selain itu hal ini juga dapat dilihat ada Tabel 3, dimana nilai mean poin pernyataan mengenai recycle merupakan poin yang tertinggi. Adanya program recycle ini kemungkinan menjadi daya tarik dan ciri khas yang semakin meningkatkan citra merek Pop! Hotel di mata konsumen. Keberadaan program recycle yang tidak mengganggu kenyamanan ketika konsumen menginap, konsumen merasa bahwa Pop! Hotel memiliki kualitas layanan yang tinggi

\section{SIMPULAN DAN SARAN}

Berdasarkan hasil penelitian di atas, dapat disimpulkan bahwa semua hipotesis terbukti positif dan signifikan. Hipotesis yang pertama dalam penelitian ini diterima. Hipotesis tersebut menyatakan adanya pengaruh positif dan signifikan dari CSR terhadap citra merek. Arti dari positif dan signifikan adalah semakin baik persepsi konsumen terhadap CSR yang dilakukan oleh Pop! Hotels, maka semakin baik pula citra merek Pop! Hotels di mata konsumen. Sesuai dengan hipotesis kedua, penelitian ini menerima bahwa citra merek berpengaruh terhadap kesetiaan pelanggan secara positif dan signifikan. Hal ini berarti semakin bagus citra merek Pop! Hotels di mata konsumen, maka kesetiaan pelanggan akan semakin meningkat. Selanjutnya hipotesis ketiga dalam penelitian ini yaitu CSR berpengaruh positif dan signifikan terhadap kesetiaan pelanggan secara langsung dinyatakan diterima. Artinya persepsi konsumen terhadap CSR Pop! Hotels mampu mempengaruhi konsumen untuk menjadi loyal. Namun hal ini tidak menutup kemungkinan bahwa ada faktor-faktor lain yang membuat konsumen menjadi lebih loyal, seperti citra merek. Hipotesis terakhir pada penelitian ini adalah adanya pengaruh positif dan signifikan dari CSR terhadap kesetiaan pelanggan dengan citra merek sebagai variabel intervening. Hasil penelitian juga menunjukkan bahwa citra merek menjadi mediator bagi pengaruh dari CSR terhadap kesetiaan pelanggan.

\section{DAFTAR REFERENSI}

Tauzia Hotel (2017). Retrieved from Pop! hotels: http://www.tauziahotels.com/en-US/OurBrands/POP!-Hotels

Badan Pusat Statistika. (2016). Surabaya dalam angka. Surabaya: Author.

Che, H. L., Miin, J., Li, C. H., \& Kuo, L. W. (2015). Online hotel booking: The effects of citra merek, price, trust, value, on purchase intentions. Asia Pacific Management Review, 20, 1-9.

CSR-Equal Chance. (2012). Retrieved from www.tauzia.com/index/csr

Du, S. B. (2011). Corporate social responsibility and competitive advantages: Overcoming the trust barrier. Management Science, 1528-1545.

Ghozali, I. (2005). Aplikasi analisis multivariat dengan program SPSS. Semarang: Badan Penerbit Universitas Diponegoro.

Hadi, N. (2011). Corporate social responsibility. Yogyakarta: Graha Ilmu.

Haliwela, N. S. (2013). Peran tanggung jawab sosial dan lingkungan oleh perusahaan (corporate social responsibility) dalam mendorong pembangunan di maluku. Retrieved from http://fhukum. unpatti.ac.id/artikel/pembangunan-hukum-dimaluku/275-peran-tanggung-jawab-sosial-danlingkungan-oleh-perusahaan-corporate-socialresponsibility-dalam-mendorong-pembangunandi-maluku\#_ftn1

Hasan, I. (2004). Analisis data penelitian dengan statistik. Jakarta: Bumi Aksara.

Hurriyati, R. (2008). Bauran pemasaran dan loyalitas konsumen. Bandung: Alfabeta.

Jogiayanto. (2011). Konsep dan aplikasi structural equation modelling berbasis varian dalam penelitian bisnis. Yogyakarta: STIM YKPN.

Kandampully, J., \& Dwi, S. (2003). The role of customer satisfaction and image in gaining kesetiaan pelanggan in hotel industry. Journal of Hospitality \& Leisure Marketing, 10(12), 1-24.

Kotler, P. (2008). Manajemen pemasaran (12th ed.). Jakarta: PT Indeks.

Kotler, P., \& Lee, N. (2005). Corporate social responsibility: Doing the most good for your company and yur cause. New Jersey: John Wiley \& Son, Inc.

Kuncoro, M. (2007). Metode kuantitaif: Teori dan aplikasi untuk bisnis dan ekonomi. (Ed.3). Yogyakarta: UPP STIM YKPM.

Mark, D., Grahame, R., \& Hammond, D. K. (2003). Kesetiaan pelanggan and kesetiaan pelanggan program. Journal of Consumer Marketing, 20(4), 294-316. 
Martinez, P., Perez, A., \& Bosque, R. (2013). CSR influence on hotel citra merek and brand loyalty. Academia Revista Latinoamericana de Administracion, 27(2), 267-283.

Ogba, I. E., \& Tan, E. (2009). Exploring the impact of citra merek on kesetiaan pelanggan and commitment in China. Journal of Technology Management in China, 4(2), 132-144.

Sarosa, W., Amri, M. (2008). CSR for better life: Indonesian context CSR untuk penguatan kohesi sosial. Jakarta: Indonesia Business Links

Singh, K. S., Islam, M. A., \& Ariffin, K. H. (2014). The relationship between corporate social responsibi- lity and citra merek. Advances in Environmental Biology, 8(9), 430-435.

Stephanie, S., \& Chandra, D. (2012). Analisa pengaruh corporate social responsibility (CSR) terhadap customer loyaty dengan citra merek sebagai variabel intervening. Surabaya: Fakultas Ekonomi Universitas Kristen Petra Surabaya.

Sugiyono. (2013). Statistik non-parametrkia untuk penelitian cet. 11. Bandung: Alfabeta.

Yi, Y., \& La, S. (2004). What influences the relationship between customer satisfaction and repurchase intention? Investgate the effects of adjusted expectations and kesetiaan pelanggan. Psychology \& Marketing, 21(5), 351-373. 